\title{
How to Train Highly Qualified Personnel? The Challenge for State Policy in the Altai Krai
}

\author{
Evgeny E. Shvakov \\ Altai State University
}

In modern conditions, human capital is the main factor of economic development. The main qualitative characteristics of human capital are formed by the system of professional education. In the Russian Federation, the system of vocational education is administered by the state. It determines the quantitative and qualitative parameters of the training system for the economy. These parameters must meet the needs of the economy in personnel. The purpose of this research is to analyze the compliance of the state policy in the field of training of highly qualified personnel with the needs of the regional economy in personnel. The article is written on the materials of the Altai territory. Based on the analysis, the priorities of the state policy in the field of training of highly qualified personnel are determined. The classification of spheres of economic activity according to the level of provision with highly qualified personnel is carried out.

Keywords: human capital, state personnel policy, training, higher education

\section{INTRODUCTION}

In current conditions, human capital is one of the most critical factors in developing the national economy. According to many researchers, it plays a major role in the growth of the gross national product (Kelchevskaya \& Shirinkina, 2019). It is the most valuable reproducible factor of modern production. The formation of human capital takes more than ten years. Education plays a leading role in the system of human capital formation - professional competencies and skills are formed within the framework of obtaining a profession. The level of their compliance with the labor market requirements determines the competitiveness of each employee, their future, and the development of the national economy. The primary role in forming the professional component of human capital is played by the higher education system (Vryonides \& Lamprianuou, 2013). In the Russian Federation, higher education is still controlled by Federal authorities. They determine the policy in the field of higher education development:

- The quality parameters of higher education;

- The necessary number of future professionals educated for the needs of the national economy.

The quantitative parameters of future professionals' education are divided into two sections:

- Professional (education distribution of highly qualified personnel by education direction);

- Territorial (setting the education volume in higher education institutions in the region in education areas).

The mentioned sections represent the essence of the government policy in the field of training highly qualified personnel. 


\section{MATERIALS AND METHODS}

An essential attribute of government policy in the field of training highly qualified personnel should be considering the necessity for such personnel in the region. It is necessary to analyze the features and prospects of regional development for these purposes and identify the current need for personnel in the region. More than that, it is crucial to develop recommendations for implementing government policy in the field of training highly qualified personnel. It is necessary for all regions, including Altai Krai.

The following data is used in the research:

- Data from official statistics (Federal State Statistics Service, 2012, 2019);

- Data of Altai Krai regional authorities on the need of the regional economy in personnel. All data is taken from open sources of information provided on the Internet (Ministry of Education and Science of Russian Federation, 2015-2019, Department of Labor and Employment of Altai Krai, 2019).

The research uses general scientific and special methods of scientific analysis - analysis and synthesis, induction and deduction, methods of statistical processing of information (grouping, comparison, economic, and mathematical modeling).

The use of these methods ensures the objectivity of the analysis and the reliability of research results.

\section{RESULTS}

While implementing this policy, it is crucial to ensure that it corresponds to the directions and prospects for the development of national and regional economies. We can comprehend this issue based on the analysis of the compliance of decisions on the development of the higher education system in the region with the directions and priorities of the development of Altai Krai.

The main criterion for training personnel is an economic activity in the region and its direction. It can be estimated by the structure of the gross regional product (Table 1).

\section{TABLE 1}

THE STRUCTURE OF THE GROSS REGIONAL PRODUCT OF ALTAI TERRITORY

\begin{tabular}{lcccc}
\hline \multicolumn{1}{c}{ Type of activity } & 2005 & 2010 & 2017 & $\begin{array}{c}\text { Change to the } \\
\text { level of 2005, \% }\end{array}$ \\
\hline Agriculture, hunting, fishing and fish farming & 16.8 & 18.2 & 13.7 & -18.4 \\
\hline Mining & 0.2 & 0.9 & 0.9 & +350.0 \\
\hline Manufacturing industries & 19.4 & 19.7 & 19.6 & +1.03 \\
\hline Electric power, gas and steam supply; air conditioning & 5.7 & 4.4 & 2.7 & \\
\hline $\begin{array}{l}\text { Water supply; water disposal, waste collection and } \\
\text { disposal, pollution elimination activities }\end{array}$ & $\ldots$ & $\ldots$ & 0.8 & -38.6 \\
\hline Construction & 6.0 & 4.7 & 6.0 & 0.0 \\
\hline $\begin{array}{l}\text { Wholesale and retail trade, repair of motor vehicles } \\
\text { and motorcycles }\end{array}$ & 14.8 & 19.0 & 14.0 & -5.4 \\
\hline Transportation and storage & 7.5 & 7.8 & 5.7 & +17.3 \\
\hline Information and communication activities & $\ldots$ & $\ldots$ & 3,1 & +20.0 \\
\hline Activities of hotels and catering companies & 1.0 & 0.7 & 1.2 & +86.5 \\
\hline Real estate operations & 5.5 & 5.7 & 9.7 & -17.3 \\
\hline Education & 5.2 & 4.3 & 4.3 & -5.0 \\
\hline Activities in the field of health and social services & 6.0 & 5.4 & 5.7 & \\
\hline
\end{tabular}

According to the table, the main branches of regional specialization of Altai Krai are manufacturing, agricultural production, and trade. The share of the branches in the gross regional product is about $15-20 \%$. 
Simultaneously, the latter two industries are characterized by a reduction in their share in the gross regional product of Altai Krai. Furthermore, the share of such industries in the gross regional product (by 15 percent or more during the study period) increases with extractive production, information and communication activities, and the activities of enterprises in the tourism industry. The development of information and communication activities is associated with an active digital transformation of economic processes. The development of tourism and recreation is determined by the fact that Altai Krai is crucial for the tourism of the Russian Federation.

Accordingly, it is logical to assume that training of highly qualified personnel should primarily focus on these segments of the regional economy. However, the study of the dynamics of indicators of the employed population (Table 2) refutes the hypothesis. It indicates the need to implement a different educational policy in the region.

TABLE 2

EMPLOYMENT OF THE POPULATION OF THE ALTAI KRAI

\begin{tabular}{lcccc}
\hline & 2010 & & 2017 & \\
\cline { 2 - 5 } Type of activity & $\begin{array}{c}\text { Number of } \\
\text { employees, } \\
\text { thousand people }\end{array}$ & $\begin{array}{c}\text { Number of } \\
\text { employees, } \\
\text { thousand people }\end{array}$ & $\begin{array}{c}\text { Dynamics by } \\
2010 \text { (change } \\
\text { in \%) }\end{array}$ & $\begin{array}{c}\text { Share of employed } \\
\text { from the total } \\
\text { number of } \\
\text { employed, \% }\end{array}$ \\
\hline $\begin{array}{l}\text { Agriculture, hunting, fishing } \\
\text { and fish farming }\end{array}$ & 205.1 & 127.4 & -37.9 & 12.6 \\
\hline Mining & 3.3 & 4.3 & +30.3 & 0.4 \\
\hline Manufacturing industries & 134.1 & 133.3 & -0.6 & 13.2 \\
\hline $\begin{array}{l}\text { Electric power, gas and steam } \\
\text { supply; air conditioning }\end{array}$ & 30.2 & 27.0 & -10.6 & 2.7 \\
\hline $\begin{array}{l}\text { Water supply; water disposal, } \\
\text { waste collection and disposal, } \\
\text { pollution elimination activities }\end{array}$ & $\ldots$ & 9.7 & $\ldots$ & 1.0 \\
\hline Construction & 55.5 & 62.8 & +13.5 & 6.2 \\
\hline $\begin{array}{l}\text { Wholesale and retail trade, } \\
\text { repair of motor vehicles and } \\
\text { motorcycles }\end{array}$ & 192.5 & 193.8 & +0.7 & 19.2 \\
\hline Transportation and storage & $\ldots$ & 67.5 & $\ldots$ & 6.7 \\
\hline $\begin{array}{l}\text { Information and } \\
\text { communication activities }\end{array}$ & 14.6 & 14.4 & -1.3 & 1.4 \\
\hline $\begin{array}{l}\text { Activities of hotels and } \\
\text { catering companies }\end{array}$ & 14.3 & 19.5 & +36.4 & 1.9 \\
\hline Real estate operations & 52.4 & 22.8 & -56.5 & 2.3 \\
\hline Education & 95.1 & 94.3 & -0.8 & 9.4 \\
\hline $\begin{array}{l}\text { Activities in the field of health } \\
\text { and social services }\end{array}$ & 83.7 & 77.1 & -7.9 & 7.6 \\
\hline
\end{tabular}

Recent years have been characterized by a noticeable change in the structure of the region's employed population. In one of the leading sectors of the economy - agriculture - the number of employed people has decreased by $38 \%$ in recent years (from 205 thousand people of the employed population in 2010 to 127.4 thousand people - in 2017). In industrial production, tourist and recreational services, education and trade, the number of employed people has not changed in the last seven years (changes within 1\%). At the same time, the IT sector of the regional economy is actively growing in the economy of Altai Krai. There is an increase in the share of this segment of the regional economy in the gross regional product structure 
and the number of the employed population. Over the past seven years, the number of employed people in the field of information and communication has increased by more than $36 \%$. Other segments of the regional economy that are experiencing an increase in the number of employed people are mining (more than $30 \%$ ) and construction (13.5\%). The total number of employed people in the field of mining (less than 4.5 thousand people in 2017) does not allow this industry to become an industry of regional specialization.

Based on the current trends in the economic development of Altai Krai, the government policy in the field of higher education should be aimed at advanced education in all areas of professions and specialties for the following industries:

- Information and communication activities;

- Construction;

- Tourist and recreational activities.

Another factor that determines the content of government policy in the field of personnel education is the shortage of personnel in the regional labor market.

In Altai Krai, according to the employment service, there are the following vacancies for specialists with higher education (data for the first half of 2019):

- Doctor (2,932 vacancies including vacancies in the field of recreation);

- Manager (1,210 vacancies);

- Teacher (832 vacancies);

- Engineer (269 vacancies);

- Programmer (142 vacancies) (Shvakov \& An, 2019).

Therefore, it can be argued that the system of training highly qualified personnel of Altai Krai should have the following directions. First of all, educating personnel for actively developing sectors of the regional economy. Second, educating personnel for areas of activity with a significant shortage of personnel. Based on this, we can add the following activities to the previously proposed list of Altai Krai economic sectors:

- Education;

- Activities in the field of health and social services.

Education of highly qualified personnel should also be a priority for these areas of activity.

The current quantitative parameters of the government policy in the field of training highly qualified personnel for the branches of the regional economy of Altai Krai are presented in Table 3 (Ministry of Education and Science of the Russian Federation 2015, 2016, 2017, 2018, 2019).

\section{TABLE 3 \\ ADMISSION TO BUDGET PLACES IN HIGHER EDUCATIONAL INSTITUTIONS OF THE ALTAI KRAI BY TYPE OF ECONOMIC ACTIVITY}

\begin{tabular}{lccccc}
\hline Type of activity & \multicolumn{4}{c}{ Number of enrolled students, people } \\
\cline { 2 - 6 } & 2016 & 2017 & 2018 & 2019 & 2020 \\
\hline Agriculture, hunting, fishing and fish farming & 307 & 296 & 277 & 257 & 266 \\
\hline Mining & 35 & 41 & 39 & 31 & 36 \\
\hline Manufacturing industries & 369 & 382 & 350 & 334 & 404 \\
\hline $\begin{array}{l}\text { Electric power, gas and steam supply; air } \\
\text { conditioning }\end{array}$ & 133 & 135 & 113 & 110 & 125 \\
\hline $\begin{array}{l}\text { Water supply; water disposal, waste collection } \\
\text { and disposal, pollution elimination activities }\end{array}$ & 63 & 52 & 63 & 66 & 65 \\
\hline Construction & 101 & 102 & 114 & 134 & 166 \\
\hline $\begin{array}{l}\text { Wholesale and retail trade, repair of motor } \\
\text { vehicles and motorcycles }\end{array}$ & 100 & 82 & 50 & 37 & 41 \\
\hline Transportation and storage & 64 & 63 & 23 & 20 & 68 \\
\hline Information and communication activities & 11 & 33 & 66 & 70 & 49 \\
\hline
\end{tabular}




\begin{tabular}{lccccc}
\hline Activities of hotels and catering companies & 350 & 336 & 375 & 369 & 424 \\
\hline Real estate operations & - & - & - & - & - \\
\hline Education & 517 & 587 & 453 & 492 & 752 \\
\hline $\begin{array}{l}\text { Activities in the field of health and social } \\
\text { services }\end{array}$ & 900 & 485 & 480 & 480 & 463 \\
\hline Other activity & 518 & 542 & 631 & 512 & 601 \\
\hline TOTAL & 3,468 & 3,136 & 3,034 & 2,912 & 3,460 \\
\hline
\end{tabular}

Universities in Altai Krai provide targeted education for all types of activities. The total number of budget places allocated for training personnel with higher education has varied in recent years from 3,000 to 3,500 places. For most types of economic activity, the number of trained specialists exceeds the future need for personnel. The mentioned fact is confirmed by comparing the data shown in Table 3 with the need for highly qualified personnel. These indicators are calculated in the forecast of the need of the economy of Altai Krai for qualified personnel for the period up to 2025 (Department of Labor and Employment of Altai Krai, 2019). A comparison of data on the number of trained specialists and the need for personnel in the region allows us to draw the following conclusions.

The number of allocated budget places covers the future need for personnel with higher education in the following types of activities:

- Agriculture, hunting, fishing, and fish farming;

- Mining;

- Manufacturing activity;

- Provision of electric power, gas, and steam; air conditioning;

- Water supply; water disposal, organization of waste collection and disposal, activities to eliminate pollution;

- Transportation and storage.

Available vacancies for these types of activities arise due to disproportions in settlement of specialists with higher education (concentration in places of education) and the discrepancy between their education and the characteristics of individual industries. The mentioned issue is solved not by increasing the number of trained specialists, but by other measures. First of all, these are measures of economic support for securing personnel in the locations of production facilities that are experiencing a shortage of personnel. As part of the educational policy, it is necessary to provide retraining, and advanced training of existing personnel and the released highly qualified labor force in the territorial entities of the region that are experiencing a shortage of individual future professionals.

Training of highly qualified future professional is not required for the following types of activities:

- Wholesale and retail trade, repair of motor vehicles and motorcycles;

- Real estate operations.

It is covered by the training of professionals with economic education in universities of the region.

The government educational policy should provide advanced personnel training to form future competencies for the remaining areas of activity. These areas are among the actively developing sectors of the regional economy and areas of activity that experience a significant personnel shortage. The view mentioned above is consistent with previous research in this area (Klyachko \& Semionova, 2018). They were named earlier and are depicted in Table 4.

\section{DISCUSSION}

We calculate the deficit in personnel for certain types of economic activity in support of the formed statement about government educational policy directions. It is determined based on the ratio of the need for personnel by type of economic activity and the estimate of the number of employed graduates at enterprises in the region in these areas. The number of employed graduates is estimated. It is based on the moving numbers of budget places in Altai Krai universities for the period of higher education and its 
adjustment to the factors of safety of students and the employment of graduates. The calculation is based on the following formulas:

$D_{i}=P_{i}-T_{i}$ and $T_{i}=C_{i-n} * K_{1} * K_{2}$,

$D_{i}-$ shortage of highly qualified personnel with specialized education in i-type of economic activity;

$P_{i}$ - the need for highly qualified personnel with specialized education in i-type of economic activity;

$T_{i}$ - number of employed graduates with specialized education in i-type of economic activity;

$C_{i-n}$ - number of students accepted for the first year of study in i-type of economic activity (data from table 2);

$n$-term of higher education in the profile of i-type of economic activity;

$K_{1}$ - coefficient of the safety of the contingent of students (formed based on observations);

$K_{2}$ - employment rate of graduates with higher education in the region (based on data from the Pension Fund of the Russian Federation in Altai Krai).

The data obtained as a result of calculations are summarized in Table 4.

TABLE 4

ESTIMATION OF THE PROSPECTIVE SHORTAGE OF PERSONNEL BY ACTIVELY

DEVELOPING SECTORS OF THE REGIONAL ECONOMY AND AREAS OF ACTIVITY EXPERIENCING SIGNIFICANT SHORTAGE OF PERSONNEL

\begin{tabular}{|c|c|c|c|c|c|c|}
\hline Type of activity & Indicator & 2020 & 2021 & 2022 & 2023 & 2024 \\
\hline \multirow[t]{4}{*}{ Construction } & $\begin{array}{l}\text { Need for highly qualified } \\
\text { personnel }\end{array}$ & 381 & 360 & 351 & 338 & 229 \\
\hline & $\begin{array}{l}\text { Need for personnel with } \\
\text { specialized education }\left(\mathrm{P}_{\mathrm{i}}\right)\end{array}$ & 240 & 227 & 221 & 213 & 144 \\
\hline & $\begin{array}{l}\text { Number of graduates with } \\
\text { specialized education } \\
\text { employed in the region }\left(\mathrm{T}_{\mathrm{i}}\right)\end{array}$ & 73 & 75 & 84 & 98 & 122 \\
\hline & Shortage of staff $\left(\mathrm{D}_{\mathrm{i}}\right)$ & 167 & 152 & 136 & 115 & 22 \\
\hline \multirow{4}{*}{$\begin{array}{l}\text { Information and } \\
\text { communication } \\
\text { activities }\end{array}$} & $\begin{array}{l}\text { Need for highly qualified } \\
\text { personnel }\end{array}$ & 480 & 493 & 496 & 501 & 507 \\
\hline & $\begin{array}{l}\text { Need for personnel with } \\
\text { specialized education }\left(\mathrm{P}_{\mathrm{i}}\right)\end{array}$ & 360 & 370 & 372 & 375 & 380 \\
\hline & $\begin{array}{l}\text { Number of graduates with } \\
\text { specialized education } \\
\text { employed in the region }\left(\mathrm{T}_{\mathrm{i}}\right)\end{array}$ & 263 & 252 & 282 & 277 & 218 \\
\hline & Shortage of staff $\left(D_{i}\right)$ & 97 & 118 & 90 & 148 & 162 \\
\hline \multirow[t]{4}{*}{ Education } & $\begin{array}{l}\text { Need for highly qualified } \\
\text { personnel }\end{array}$ & 3,458 & 3,245 & 3,210 & 2,988 & 2,843 \\
\hline & $\begin{array}{l}\text { Need for personnel with } \\
\text { specialized education }\left(\mathrm{P}_{\mathrm{i}}\right)\end{array}$ & 2,109 & 1,979 & 1,958 & 1,823 & 1,734 \\
\hline & $\begin{array}{l}\text { Number of graduates with } \\
\text { specialized education } \\
\text { employed in the region }\left(\mathrm{T}_{\mathrm{i}}\right)\end{array}$ & 360 & 409 & 315 & 342 & 523 \\
\hline & Shortage of staff $\left(\mathrm{D}_{\mathrm{i}}\right)$ & 1,749 & 1,570 & 1,643 & 1,481 & 1,211 \\
\hline
\end{tabular}




\begin{tabular}{|c|c|c|c|c|c|c|}
\hline \multirow[t]{4}{*}{$\begin{array}{l}\text { Tourism and } \\
\text { recreation }\end{array}$} & $\begin{array}{l}\text { Need for highly qualified } \\
\text { personnel }\end{array}$ & 276 & 261 & 257 & 249 & 243 \\
\hline & $\begin{array}{l}\text { Need for personnel with } \\
\text { specialized education }\left(\mathrm{P}_{\mathrm{i}}\right)\end{array}$ & 25 & 24 & 23 & 22 & 21 \\
\hline & $\begin{array}{l}\text { Number of graduates with } \\
\text { specialized education } \\
\text { employed in the region }\left(T_{i}\right)\end{array}$ & 8 & 24 & 49 & 52 & 36 \\
\hline & Shortage of staff $\left(\mathrm{D}_{\mathrm{i}}\right)$ & 17 & 0 & -26 & -30 & -15 \\
\hline \multirow[t]{4}{*}{$\begin{array}{l}\text { Health and social } \\
\text { services }\end{array}$} & $\begin{array}{l}\text { Need for highly qualified } \\
\text { personnel }\end{array}$ & 1,475 & 1,236 & 1,108 & 1,068 & 962 \\
\hline & $\begin{array}{l}\text { Need for personnel with } \\
\text { specialized education }\left(\mathrm{P}_{\mathrm{i}}\right)\end{array}$ & 1,077 & 903 & 809 & 779 & 702 \\
\hline & $\begin{array}{l}\text { Number of graduates with } \\
\text { specialized education } \\
\text { employed in the region }\left(T_{i}\right)\end{array}$ & 702 & 698 & 376 & 372 & 371 \\
\hline & Shortage of staff $\left(\mathrm{D}_{\mathrm{i}}\right)$ & 375 & 205 & 433 & 427 & 331 \\
\hline
\end{tabular}

These data indicate that the state educational policy does not contribute to providing the region's economy with the necessary personnel. For all types of activities that currently have a shortage of highly qualified personnel (education, health, and social services) and actively developing sectors of the economy (construction, information, and communication activities), except for activities in the field of tourism and recreation, the shortage in personnel will not be overcome. At the same time, it remains critical for the education system of the system in the forecasted period. The shortage of personnel is even more significant in the field of information and communication and the health and social services system.

\section{CONCLUSION}

The circumstances mentioned above determine the search for possible solutions; they include the following. First of all, it is necessary to review the number of budget places allocated to the region to train personnel for these types of activities:

- Construction (at least 200 people in the next four years);

- Information and communication activities (at least 450 people in the next four years);

- Education (at least 1,300 people in the next four years);

- Health and social services (at least 750 people in the next four years).

Second, to increase the target set for the sectors with budget support- education, health, and social services. The use of target recruitment mechanisms makes it possible to increase the number of graduates employed in the region and optimize their distribution across the territory of Altai Krai. It solves the issue of concentration of highly qualified personnel in places of their training (Barnaul, Biysk).

Third, to provide personnel for the education system of the region and use a target set for teacher training and training in areas that correspond to the profile of school subjects. It applies to the training of mathematicians, physicists, biologists, and geographers.

Fourth, to form a system of retraining of engineering, pedagogical, and medical personnel. Retraining of personnel can become a significant factor in overcoming the deficit in certain specialties. Generally, it concerns solving the problem of shortage of teaching and engineering personnel. Receiving pedagogical education by specialists with higher education and skills in the field of school subjects will help to overcome the shortage of teaching staff. The organization of a retraining system for engineering personnel will bring their qualifications in line with the labor market requirements. 


\section{REFERENCES}

Department of labor and employment of the Altai Krai. (2019). Forecast of the economy of the Altai Krai need for qualified personnel for the period up to 2025. Retrieved from https://portal.aksp.ru/cms_data/usercontent/regionaleditor

Federal State Statistics Service. (2012). Region of Russia. Socio-economic indicators 2012. Retrieved from https://rosstat.gov.ru/folder/210/document/13204

Federal State Statistics Service. (2019). Region of Russia. Socio-economic indicators 2019. Retrieved from https://rosstat.gov.ru/folder/210/document/13204

Kelchevskaya, N.R., \& Shirinkina, E.V. (2019). Regional determinants of effective use of human capital in the digital economy. Regional Economy, 15(2), 465-482.

Klyachko, T.A., \& Semionova, E.A. (2018). Contribution of education to the socio-economic development of Russian regions. Regional Economy, 14(3), 791-805.

Ministry of Education and Science of the Russian Federation. (2015, February 8). "Announcement of an open public competition for the distribution of admission control figures for specialties and areas of training and (or) enlarged groups of specialties and areas of training for training in educational programs of higher education at the expense of budget allocations of the Federal budget for the 2016-2017 academic year". Moscow, Russia.

Ministry of Education and Science of the Russian Federation. (2016, February 11). Order of

"Announcement of an open public competition for the distribution of admission control figures for specialties and areas of training and (or) enlarged groups of specialties and areas of training for training in educational programs of higher education at the expense of budget allocations of the Federal budget for the 2017-2018 academic year". Moscow, Russia.

Ministry of Education and Science of the Russian Federation. (2017, February 9). Order of

"Announcement of an open public competition for the distribution of admission control figures for specialties and areas of training and (or) enlarged groups of specialties and areas of training for training in educational programs of higher education at the expense of budget allocations of the Federal budget for the 2018-2019 academic year". Moscow, Russia.

Ministry of Education and Science of the Russian Federation. (2018, February 12). Order of "Announcement of an open public competition for the distribution of admission control figures for specialties and areas of training and (or) enlarged groups of specialties and areas of training for training in educational programs of higher education at the expense of budget allocations of the Federal budget for the 2019-2020 academic year". Moscow, Russia.

Ministry of Education and Science of the Russian Federation. (2019, March 14). Order on "Approval of the total volumes of admission control figures for specialties and areas of training and (or) enlarged groups of specialties and areas of training for training in educational programs of higher education at the expense of budget allocations of the Federal budget for the 2020-2021 academic year" (No 137). Moscow, Russia.

Shvakov, E.E., \& An, E.A. (2019). HR strategy of the region in the context of structural adjustment of its economy. Economics and Management: Problems and Solutions, 2(12), 27-32.

Vryonides, M., \& Lamprianuou, I. (2013). Education and social stratification across Europe. International Journal of Sociology and Social Policy, 33(1/2), 77-97. 